European journal of American studies

Special Issue: Media Agoras: Islamophobia and Inter/ Multimedial Dissensus

\title{
Holy Terror!: Islamophobia and Intermediality in Frank Miller's Graphic Novel
}

\section{Frank Mehring}

\section{(2) OpenEdition \\ Journals}

Electronic version

URL: https://journals.openedition.org/ejas/16274

DOI: $10.4000 /$ ejas. 16274

ISSN: 1991-9336

Publisher

European Association for American Studies

Electronic reference

Frank Mehring, "Holy Terror!: Islamophobia and Intermediality in Frank Miller's Graphic Novel", European journal of American studies [Online], 15-3 | 2020, Online since 29 September 2020, connection on 08 July 2021. URL: http://journals.openedition.org/ejas/16274 ; DOI: https://doi.org/10.4000/ejas.16274

This text was automatically generated on 8 July 2021.

Creative Commons License 


\title{
Holy Terror!: Islamophobia and Intermediality in Frank Miller's Graphic Novel
}

\author{
Frank Mehring
}

Frank Miller-the iconic writer/artist of Sin City and 300 brings you a no-holdsbarred action thriller for the modern era. Join The Fixer, a brand new, hard-edged hero as he battles terror in the inaugural release from Legendary Comics:

Frank Miller's Holy Terror-coming September.

"Holy Terror," Super Robot Mayhem ${ }^{1}$

\section{Introduction}

The graphic artist Frank Miller is next to Art Spiegelman and Alan Moore one of the most celebrated innovators of the comics medium. With what I have called elsewhere the "art of aesthetic omission,"2 Miller reduces his figures moving through space to their bare minimum paving the way to an iconographic storytelling that re-invigorated the medium in the 1980s. Via innovative storytelling and visual layouts he has changed the perception of the medium, making it fit for critical analyses in the New York Times and other high-quality media outlets (see Waid ix). Miller represents an original force in the field of graphic novels who pushes the medium into new territories thereby exploring "subject matter previously untouched" (Brownstein, flap, see also Duncan, Smith, Levitz 86). One such territory is Islamophobia and terrorism. Miller's graphic novel Holy Terror, conceived in the wake of $9 / 11$ and released on the $10^{\text {th }}$ anniversary of the terror attacks is a revealing case in point. The graphic novel depicts a Batman-like hero who, after suffering from the explosion of a dirty bomb in Empire City-a thinly veiled version of Batman's Gotham City $^{3}$ which in turn functions as a fictionalized stand-in for New York City-turns to battling Islamic jihadists on American turf. The story follows the Fixer and his sidekick the cat burglar Natalie Stack (a version of Catwoman, the enduring enemy and love-interest of Batman) as they team up to stop the Al-Qaeda conspiracy to destroy Empire City. In the tradition of the famous Marvel 
comic of Captain America fighting Adolf Hitler in March 1941, ${ }^{4}$ the cover of Holy Terror shows the white American superhero punching a terrorist with a turban. His fist hits the terrorist's face, knocking out his teeth. On a metaphorical level, the iconographic cover pits determined American white men against violent Muslim terrorists whose facial markers are blackened out in a process of Othering. The violent response of the Fixer to a stereotypical cartoon of Muslim terrorist becomes embedded in the marketing campaign. At the time of its release, the publisher Legendary Comics advertised the graphic novel resorting to blockbuster promotion aesthetics and an online video trailer. ${ }^{5}$ The promotion tagline asked potential readers to join ranks with Miller's novel crime fighter ten years after the terrorist attacks on the World Trade Center: "Join The Fixer, a brand new, hard-edged hero as he battles terror."

This article ties in with this special EJAS edition's concept of "media agoras" to explore how Islamophobia has been mediated and how media systems of the twenty-first century forge Orientalism and Islamophobia into new shapes (see introduction) asking: How does Frank Miller's aesthetics of silhouette bodies reframe Islamophobia in an interpictorial and intermedial discourse of images?7 To what extent do Miller's graphic stylizations of Islamophobia remediate elements of his previous work on fictional (super)heroes and historical leaders from Batman to the 300 Spartans? I argue that Miller's visual narrative participates in the Islamophobic discourse of American popular culture by appropriating a wide array of popular culture visual archives for a propagandistic call for Muslim "Othering."

3 Holy Terror references news media, film makers, politicians, comic book heroes, 9/11 photography, and, of course, Miller's own oeuvre with its specific stylization of "grace under pressure" Hemingway style, ${ }^{8}$ noir narratives, silhouette aesthetics, aggressive romanticism, and hard-boiled rhetoric in the vein of Dashiell Hammett or Raymond Chandler. ${ }^{9}$ The graphic novel represents what I conceive as a virtual agora where different media converge to negotiate public discourses on Islamophobia. ${ }^{10}$ The term 'agora' refers to an open space in ancient Greek cities serving as an assembly area and a place for commercial, civic, social, and religious activities. In its extended use, the term refers to an "assembly for discussion or decision; (hence) any environment or world of social intercourse, exchange, or commercial dealings" (OED2). ${ }^{11}$

4 Islamophobia emerged as an essential part of public discourse in the U.S. after 9/11. It became part of a culture of patriotic self-fashioning. In many cases, Americans defined themselves in opposition to Islam. The "highly emotive issue" (Allen 376) that informed the discourse over Islamophobia was fueled by a sense of fear of Islam. It became part of a variety of media including film, television, newspapers, books, and internet blogs. ${ }^{12}$ I will turn to the medium of graphic novels to first reveal how Miller's narratives of (super)heroes have become complicit with Islamophobic responses to the crisis of 9/11, second, to trace the discourse of Islamophobia in the post-9/11 United States on Miller's work and, third, to explore how it interlinks with the concept of terrorism.

5 To do so, I will offer an iconological reading turning to visual media including film and photography and graphic symbols. I will place particular emphasis on processes of mediation and remediation of silhouette aesthetics. ${ }^{13}$ As a form of visual art, graphic novels such as Holy Terror are part of a "network of repertoires and conventions," as Udo Hebel argues in a different context (404). They allow us to identify moments of intercultural contact in different media environments and trace individuals (or groups) of cultural mobility, translators, and intermediaries. In order to understand the 
network, implications, and intermedial exchange (see Rajewsky 46) for the aesthetic construction of Miller's visualization of a graphic "war on terror," we have to understand the connection between the image and the premises underlying our frame of reference. "Islamophobia must be seen as a cultural phenomenon, crafted, disseminated, and circulated through medial practices such as television reports, films, literary texts, and the Internet," as Brandt argues in "Fear of an Islamic Planet? Intermedial Exchange and the Rhetorics of Islamophobia." If we understand the processes of mediation and remediation (see Bolter and Grusin 3) that take place in the Othering of Muslims, we can reveal racial narratives that have pervaded the discourse in the public sphere. The medium of graphic novels adds an additional dimension to the kind of media agoras mentioned before. As Derek Parker Royal explains in the preface to Multicultural Comics, "given its reliance on symbols and iconography, comic art speaks in a language that is accessible to a wide audience, transcending many of the national, cultural, and linguistic boundaries imposed by other media and giving it a reach that is as democratic as it is immediate" (Royal x). In the following, I will explore the confrontational rhetoric of Holy Terror and the limits of its democratic reach.

\section{Frank Miller's Visual Rhetoric of Aestheticized Violence}

Frank Miller's visual rhetoric of aestheticized violence in Holy Terror goes back to the beginnings of his career. Miller began to make his mark on superhero comics with his visual approach to Daredevil, written by Roger McKenzie in 1979. In Ronin, the six-issue miniseries he did for DC in 1983-4, he started to shift his attention to creative visual storytelling in order to foster a new narrative tone and level of drama. Here, Miller successfully blended Japanese manga techniques (particularly Katsuhiro Otomo's work on Akira) with Franco-Belgian comic traditions (borrowing from Alain Saint-Organ, Hergé, and others) to evoke a dark, dystopic New York of the future. A few years later, in his epochal Dark Knight miniseries for DC Comics (1986), he found in Batman a superhero whose persona could be translated into an expressionist aesthetics of a shadowy doppelgänger. Miller emphasized the violent roots of the Batman character as markedly different from the campy TV show of the 1960s. The gritty and noir vision of vigilantism of the caped crusader lent itself to an exploration of the narrative potential of silhouette figures in dark urban environments. Emphasizing the criminal underworld, corrupt cops, bad guys, femme fatales, and heroes of the urban jungle in, for example, his highly lauded crime series Sin City (June 1991 and April 2000), Miller quickly emerged as an iconic artist who excelled in the use of silhouette aesthetics. Sin City explores the narrative potentials of silhouette bodies and urban landscapes, featuring a highly evocative textual and visual style that activates memories, fantasies, dreams, and nightmares associated with global cities.

7 While Miller honed his skills of story-telling via silhouettes, the issue of extreme visual and textual reduction has contributed to a controversial discourse on Islamophobia in the context of Holy Terror about the U.S. fight against terrorism after $9 / 11 .{ }^{14}$ My aim is to identify general visual patterns and intermedial references in Holy Terror in order to reveal opposite readings in Miller's signature visual rhetoric: the use of silhouette aesthetics. ${ }^{15}$ 
8 The visual aesthetics of silhouettes often evoke a sense of kinetic energy, rebellious attitude, and performance styles as can be clearly seen in the opening pages of Holy Terror where we follow the Fixer chasing Natalie Stack in a rousing action sequence over the roof-tops of Empire City. To what degree can silhouettes contribute to a visual rhetoric in Miller's graphic novels that both affirm American patriotism and undermine the intention of generating patriotism in times of crisis? As media critic W.J.T. Mitchell explains, "the power of images to influence human behavior" has received particular emphasis in academia. ${ }^{16}$ At the time of the release of Holy Terror, he identified the years after 9/11 as an "epoch of the war on terror" (xix). Regarding images, he argued that the most important question should not only be what images mean but what kind of cultural work they actually do (xix). After the end of the Obama presidency with its emphasis on a post-racial society, the U.S. moved towards an isolationist agenda of "America first" and a return to a whole-sale process of Muslim Othering. It is revealing to revisit and analyze Frank Miller's Holy Terror as a graphic novel that might not have been lagging behind in its relevance to American cultural politics but rather a visionary product that captured a specific mood of people who were not necessary part of the traditional comic book fanbase of Miller's revisionist Batman publications. The question then is: How do images of terror and Islamophobia evolve, mutate, and re-circulate? What kind of emotions and effects are produced that -and here I am referring to an expression that Mitchell used evoking Raymond Williams-animate "the structure of feeling that characterize our age" (xix)?

One can trace the ambivalent use of silhouette bodies in media culture in three stages. First, the emergence of silhouette cutouts in eighteenth-century Europe. Second, in transatlantic and inter-American processes of transmission in silhouette aesthetics over the course of the nineteenth and twentieth centuries, with a specific focus on the different styles of silhouettes used by artists to contribute to the project of cultural self-recognition during the Harlem Renaissance (such as Winold Reiss, Aaron Douglas, and Miguel Covarrubias). Third, understanding the palimpsest situation in the use and remediation of silhouettes in the late twentieth and early twenty-first centuries. ${ }^{17}$

By focusing on the intersection of American graphic novels, art history, media studies, and American studies, I will identify intermedial contacts; trace individuals of cultural mobility, translators, and intermediaries; and map interpictorial clusters (in the sense of Udo Hebel) in which racialized silhouetted bodies as represented by Muslim "Others" in Holy Terror (re)emerge. ${ }^{18}$

\section{Silhouettes in Transatlantic Contexts}

11 At the very time when silhouettes had become seemingly obsolete at the turn of the twentieth century, Emily Nevill Jackson called for a precise historical overview to bring to attention the art of silhouettes in the United States. In 1911, she argued: "Surely it is high time the art of black profile portraiture had a historian of its own and the great masters of silhouette portraiture were rescued from oblivion. Shadows are impalpable things which fade away almost before we are aware of their existence" (5). How can we describe silhouettes? The most general definition in the Oxford English Dictionary identifies a silhouette as a "dark outline," for example, "a shadow in profile," which appears "against a lighter background." When it comes to the representation of human beings, silhouettes refer to "a portrait obtained by tracing the outline of a profile, head, 
or figure by means of its shadow or in some other way, and filling in the whole with black; an outline portrait cut out of black paper; a figure or picture drawn or printed in solid black." ${ }^{19}$ The process of cutting a silhouette can also be reversed so that the portrait is cut as a hole and then placed on dark material to bring about the profile. ${ }^{20}$ During the period of romantic classicism with its interest in the classical past, the mythical story of the first silhouette artist and the artistic practice gained particular attention. Jean-Baptiste Regnault's work entitled The Origin of Painting from 1785 is merely one of many artworks from the era to capture the romanticized version of shadow traces..$^{21}$ In his successful book Physiognomische Fragmente zur Beförderung der Menschenkenntnis und Menschenliebe, published in 1775, Johann Caspar Lavater argued that the silhouette was the most truthful and immediate reflection of a human being; in the profile, one could trace a person's character. Lavater built on the theories of the Dutch physician Petrus Camper who showed via changes in the profile that human beings moved away from the world of animals. Lavater's pseudoscience gained great popularity among many intellectuals. His work would later become part of a racist discourse on colonial cultural politics and racial profiling.

The connection between immigration, urbanization, and changing silhouette aesthetics can be traced to the growing preoccupation of publishers with pictorial media in the early twentieth century and the rise of urbanization on both sides of the Atlantic. As Jan Baetens has argued, "[v]isual print culture and visual storytelling [emerged] by way of engraving" (1138). The woodcuts of the early twentieth century are informed by Expressionism in the fine arts, the visual codes of Expressionist silent cinema, and the cartoons of newspapers and journals (Kuper 7-9). A striking example of visual storytelling in print media can be found in Europe at the beginning of the twentieth century with so-called woodcut novels. The Belgian-born artist Frans Masereel (1889-1972) coined the term "roman in beelden" (novel in pictures). Masereel created stories about modern urban dwellers surrounded by cityscapes, which seemed to promise liberation but also embody a sense of claustrophobia, violence, and selfalienation..$^{22}$ Like his preceding effort, The Passion of Man (1918), Masereel's work influenced a number of artists working in other media such as writing, music, and film. For example, in the United States, the German-trained woodcut artist Lynd Ward (1905-1985) appropriated Masereel's technique to provide an iconographic visual account of American urban life during the Great Depression in works such as Madman's Drum (1930) and Wild Pilgrimage (1932). ${ }^{23}$

13 In the 1920s, silhouettes underwent a remarkable transformation. The collaboration between immigrant artists from Europe with Latin American and African American artists led to a reevaluation of silhouette aesthetics that became most prominently pronounced in works related to African American culture. The "New Negro" movement utilized silhouette figures to recodify associations of silhouettes by opening up new perspectives on African American music, literature, theater, and dance. Following aesthetic strategies of the German immigrant artist, designer, and teacher Winold Reiss, Aaron Douglas, the so-called "dean of African American painters" and leading visual artist of the Harlem Renaissance, set out to counter stereotypical, often degrading images of African Americans with the very visual genre that is prone to stereotyping because of its radical omission of detail: silhouettes.$^{24}$ Turning to mural art and illustration, Douglas wanted to portray African American lives, dreams, and realities to provide a new sense of racial uplift, self-recognition, and general 
appreciation of the contributions of African Americans to modern American culture. Silhouettes played a key role in his artistic vision. One could argue, as I have done elsewhere, ${ }^{25}$ that in the context of the so-called New Negro Movement during the 1920, silhouettes became "black," that is, they became associated with a mask-like coolness of African American urbanites. The silhouette aesthetics of Frank Miller draw on this cultural process of recoding, recycling, and reframing silhouettes as can be seen for instance in his work on Sin City.

\section{Silhouetted Stereotypes of Terror and Islamophobia}

Stereotypes represent a recognizable generalization of a type. Particularly in caricature, as Duncan, Smith, and Levitz claim, generations of characters are quickly established via physique, hair, posture, clothing or facial expressions (114). Miller's appropriation and modification of silhouette aesthetics is related to extreme forms of male violence and hyper-sexualized female bodies. ${ }^{26} \mathrm{He}$ follows a different venue than, for example, the artist Kara Walker who has almost single-handedly brought new attention to the complex frames of reference of silhouette cutouts. "The silhouette says a lot with very little information, but that's also what the stereotype does. So I saw the silhouette and the stereotype as linked," says Walker. ${ }^{27}$ Her work highlights the potential of silhouettes to intervene in the current discourse on race, class, and gender. ${ }^{28}$ In Walker's work, black silhouettes critically address the trauma of slavery in drastic exaggerations of violence and sex. Provocative images are intrinsically linked to an American narrative of painful exploitation and what Toni Morrison has described as a white success story realized "on the backs of blacks." ${ }^{29}$

Provocation is a key concept in the black-and-white silhouette aesthetics of Miller's oeuvre. "I love to provoke, because part of the purpose of art is provocation. And part of my job is to wake people up" (Itzkoff, NYT). In Holy Terror, we can see how racially coded silhouetted stereotypes are transferred from the iconography of African Americans to that of Muslims. ${ }^{30}$ In the following I will map, analyze and evaluate four stereotypical patterns of visualizing Islamophobia in Miller's graphic novel via interpictorial readings: 1) visualizations of terror 2) visualizations of terrorists, 3) violence against terrorists, and 4) visualizations of torture. I will end by putting the work in context with Miller's racist comments in his weblog.

\section{Visualizations of Terror}

The black and white aesthetics often reflect the world-view of Miller's characters that live in urban environments dominated by brutality, violence, sexual thrills and situations in which heroes need to take up arms against monolithic adversaries. While Holy Terror features similar tropes of violence, vigilantism, and the fight for freedom and justice with Miller's earlier work, particularly on the Batman figure, the references to Islamophobia appeared first in his epic work on 300 (1998). The ancient battle from September $480 \mathrm{BC}$ at the arrow coastal pass of Thermopylae (the so-called "Hot Gates") is turned into a mythical tale of heroism at the birth of ancient democracy against the army of the Persian king Xerxes.

THE LAW. WE DO NOT SACRIFICE THE RULE OF LAW TO THE WILL AND WHIM OF MEN. THAT IS THE OLD WAY. THE OLD, SAD, STUPID WAY. THE WAY OF XERXES 
AND EVERY CREATURE LIKE HIM. A NEW AGE IS BEGUN. AN AGE OF GREAT DEEDS. AN AGE OF REASON. AN AGE OF JUSTICE. AN AGE OF LAW AND ALL WILL KNOW THAT THREE HUNDRED SPARTANS GAVE THEIR LAST BREATH TO DEFEND IT. (300, unpaginated)

Rather than historical accuracy and realist conventions, Miller follows a different path. The approach can be described as a visualization of "emotional truth" (Zachar 4) that transforms a specific historical event into a universal narrative of heroism, sacrifice, and patriotism. The stylized historical narrative focusing on ethnic identity and hyperviolent battles against Middle-Eastern enemies for the cause of democratic Sparta becomes even more defined in Miller's prequel/sequel entitled Xerxes (2019) where the Greek leader Aeskylos reflects on the cause and rightfulness of the bloody fight against the Persian invaders: "THOUSANDS DEAD. HUNDREDS OF THEM OURS. ALL FOR AN IDEA. AN IDEA, AN EXPERIMENT WE CALL DEMOCRACY. COULD IT BE WORTH ALL THIS? IT HAS TO BE WORTH IT. IT HAS TO BE" (unpaginated). The ensuing battles in both 300 and Xerxes resonate strongly with the political agenda to reframe American foreign policy as a War on Terror, and to fight two wars in the Middle East after the attacks on the World Trade Center in New York City. ${ }^{31}$ In 300, Xerxes is visualized as an effeminate exotic warrior with slit eyes and protruding lips making him a stark counterpart to the hypermasculine Spartans. Compared to the muscle-packed Spartans, his tight silhouette is drawn like a slender female actress who is in awe with her looks.

With Holy Terror, Miller makes his stylized figures explicitly complicit with a specific patriotic agenda re-defining what appeared to be battles against crime and criminals as a form of vigilante revenge against terror and terrorists. ${ }^{32}$ On a textual level, Holy Terror opens with an Islamist call for battle in large white letters over a black background: "IF YOU MEET THE INFIDEL, KILL THE INFIDEL.-MOHAMMED" (unpaginated). ${ }^{33}$ While taken out of context, Miller reduces the Quran, the central religious text of Islam, to an attack on the religious and political values of the United States within the framework of 9/11. Presented within the covers of a graphic novel entitled Holy Terror, the phrase is linked to the public discourse on Jihad which is often translated as a "holy war" (against the infidel). ${ }^{34}$

In Miller's work, "KILL THE INFIDEL" becomes a call for terror visually emphasized by coloring the letters in red. By implication, this reference at the beginning of Holy Terror suggests that Islam is a religion of violence that supports terrorism. This connection between terror and destruction is preceded by a double-page of black nails exploding over the entire layout suggesting a nail bomb. The red background implies the bleeding of the victims and sets an emotional tone by activating news images of American terror attacks from 9/11 via the Times Square bombing to the Boston Marathon bombing. ${ }^{35}$ After the call to "kill the infidels", Miller zooms in on the visualization of terror. The following double page shows a stylized combination of a silhouetted Statue of Liberty and the statue of justice. Instead of the torch, the blind-folded female figure raises a symbolic balance of justice in front of the skyline of an imaginary version of New York evoking the silhouettes of the World Trade Center and the Empire State Building. While the statue of justice would hold a sword in her right hand, Miller alludes to the Declaration of Independence suggesting that the following account of Holy Terror judges the enemy of the U.S. without prejudice purely on the basis of American values. The sky is filled with debris of a large-scale explosion. The references to nails and debris of an explosion appear throughout the graphic novel as a kind of leitmotif for visualizing what could be called "Muslim terror." The text blurbs emphasize the nature of 
unexpected terror. “THE AIR BURNS." “THERE'S NO WARNING." “NO WARNING AT ALL" (unpaginated).

The stark black-and-white scenery evokes the kind of scattered debris that filled the air after the planes flew into the World Trade Center. This image immediately implies the kind of "us vs them" and "you are either with or against the terrorists" narrative that informed the weeks and months after the attacks on 9/11. The collection of photographs of The Atlantic magazine on icongraphic images of 9/11 that entered cultural memory allows us to understand the remediation of documentary photography and video sequences into the graphic novel's visualization of terror. ${ }^{36}$ The majority of panels of Holy Terror continue the pattern of debris flying through the air as a metaphor that terrorist attacks have shaken the whole way of life of Empire City's inhabitants-it feels as if the attacks have "polluted" the very air they are breathing. This visual device connects all of the action of the Fixer with what appears to be a reminder of the constructed connection between Muslims and terror on the U.S. at the beginning of Holy Terror. The visual pattern can be traced in The Atlantic photographs titled "Smoke pours from a gaping hole and the upper floors of the World Trade Center's North Tower, shortly after hijackers crashed American Airlines Flight 11 into the building on September 11, 2001 in New York City" (ill. 2), "Flames erupt from the South Tower of the World Trade Center, after it was struck by hijacked United Airlines Flight 175, in New York City, on September 11, 2001. The aircraft crashed into the tower traveling at a speed of approximately 586 miles per hour" (ill. 4) or "Debris rains down on the street as the South Tower of the World Trade Center collapses after hijacked planes crashed into the towers on September 11, 2001 in New York City" (ill. 21).

On the pages of Holy Terror, the Fixer and Natalie are repeatedly thrown through the air and get hurt due to explosions. Onomatopoetic expressions such as "SKAK", "THUNK" or "THUD" phonetically imitate the sounds that the comic panel tries to suggest in stark black and white colors. While on the one hand, these sound effects are reminiscent of sonic effects in films, the figures resemble and evoke, on the other hand, the haunting photographs that show people jumping from the World Tower such as "People hang from the windows of the North Tower of the World Trade Center after a hijacked airliner hit the building September 11, 2001 in New York City" (ill. 10), "A man leaps to his death from a fire and smoke-filled North Tower of the World Trade Center, on September 11, 2001 in New York City after terrorists crashed two hijacked passenger planes into the twin towers" (ill. 11), or "A man jumps from the North Tower of New York's World Trade Center on Tuesday, September 11, 2001" (ill. 13). Other large-scale panels highlight the destruction at the site of explosion and the human toll. Like photographs that reveal familiar items of everyday-life at unlikely locations, Miller transforms the photographic archive in his signature black and white renderings by showing a green car facing upwards or an oversized red shoe in-between heaps of rubble in the destroyed city center. Film director Steven Spielberg has successfully explored a similar aesthetic technique in his black and white movie Schindler's List (1993). In one scene, a little girl with a colorized red dress walks through the street depicting the liquidation of the Kraków ghetto. When later Schindler sees her exhumed dead body, he recognizes her among the many victims of the Nazi terror regime. Like Spielberg, Miller uses the occasional appearance of color to personalize and humanize the horror of terrorist attacks but, in contrast to Spielberg, serve a very different political purpose. Due to the abstract nature of silhouette aesthetics, the black and white silhouettes in Holy Terror allow readers to project their own fears, anxieties, and 
mediated fantasies of Islamophobia onto the masterful examples of what I call the "art of omission." ${ }^{37}$ This aesthetic strategy invites readers to fill in blanks and-in the case of Holy Terror-thus compels them to become complicit with the racist discourse of Islamophobia it promotes.

On the following pages, the reader will join the heroic fighters in the tradition of Marvel comics. Instead of battles against fictitious supervillains, Miller's heroes set out to take revenge, to insult, to torture and to destroy cartoonish versions of the actual terrorists responsible for attacks on the United States. The violent, propagandistic, and racist example of Islamophobia in the graphic novel has, as I will reveal in the following pages, larger repercussions on the work of Miller. ${ }^{38}$

\section{Visualizations of Terrorists}

Much like the confrontations in other works of Miller, ${ }^{39}$ Holy Terror pits its heroes against an enemy that outnumbers the self-acclaimed fighters for peace, freedom and justice by far. One of the tools Miller employs is a list of racial profiling embedded between images of extreme mayhem. The detonation of a bomb in Empire City is visualized by abstract black and white renditions of debris, nails and razor blades. Like a phoenix out of Empire City's ashes the American heroes rise to engage in their vigilante fights. In between, Miller injects profiles of Empire City's victims-men and women, young and old. The two figures in black hunched together on the lower left page surrounded by beams and havoc of destruction offer a stark contrast to the caricatures of citizens on the opposite page. The inked outlines fade to gray and white until they become empty signifiers on the following double page. The empty squares invite the reader to fill in the blanks with their own projections and to answer the question "How many of my neighbors have they murdered?"-a question actually asked by one of the silhouetted heroes. Miller turns to a style of illustrations that takes its cues from journalistic photographs depicting the destruction of ground zero and collages of portraits of $9 / 11$ victims which circulated on social media and television. The clear-cut silhouettes become integrated in the visual language of destruction by adding white noise to the characters thereby increasing the level of abstraction. ${ }^{40}$

Silhouettes, more than other visual stylizations, function along the lines of offering a sense of closure. "Closure is a term you learn in art school. It is the teasing of the viewer's eye to complete the image you not-so-entirely present. You, the storyteller, leave your piece of work deliberately incomplete, so that the viewer becomes an active, creative participant, finishing the job and thereby enjoying it all the more," Miller argues in his blog on "When in Doubt, Black it Out" (http://sequart.org/magazine/ 7644/frank-miller-controversy/).

One can trace many interpictorial references to Islamophobia to understand how Miller's work ties in with other media. For example, a cover of season 4 of the television series Homeland shows dark silhouetted women wearing a burka. These are nameless masses in black with no eyes and personality. Only the white female protagonist in red turns to the viewer with a nervous look. The striking image draws on interpictoral and intertextual references to the little red riding hood fairy tale. Like the innocent girl in the Brother Grimm story, Carrie Mathison, the CIA officer with bipolar disorder, needs to fight the terrorist mastermind Haissan Haqqani in Afghanistan and Pakistan. Other post-9/11 series such as The West Wing and 24 follow intermedial aesthetic strategies to 
create a specific sense of disorientation and paranoia. However, in contrast to Holy Terror, these series offer an ambivalent space for "interpretation, consent and dissent" that transcends a clear-cut visualization of Islamophobia as Brigitte Findlay has shown in this special issue.

\section{Visualizations of Violence against Terrorists}

Let me turn to another image that shows the Fixer and Natalie taking on Muslim terrorists that-among other visual points of reference-reflect the theme of the battle at Thermopylae. Instead of the Spartans with their shields and arrows we see the two heroes shooting and clawing at the enemy in full-blooded anger driven to destroy the enemy. The drawing on the opposite side offers a gruesome fantasy of brutality, rage, and revenge coupled with a reference to the intersection of violence and sexuality. In a key panel of Holy Terror, we see the Fixer hovering over a crowd of terrorists. He shoots them down in a fit of fury. Standing next to him, Natalie Stack engages in a fistfight with terrorists who have bomb belts around their waists. Her silhouetted body emphasizes her large breasts while she manhandles the terrorist. The scene is accompanied by a single blurb that frames traditional diplomatic approaches to conflict of past administrations as weak, appropriate and ineffective. The textual reference can be read as a sick joke on the failure of finding a diplomatic solution. "WE ENGAGE IN POSTMODERN DIPLOMACY" (unpaginated).

The caricatures of the Muslim Other are in line with stereotypes that have been part of Hollywood representations of the "Arab Other" best described by Sut Jhally in his documentary Reel Bad Arabs (2006), based on Jack G. Shaheen's 2001 book of the same title. Based on the analysis of Hollywood films of the last more than hundred years, Jhally and Shaheen conclude that there are patterns to present Arabs as "brute murderers, sleazy rapists, religious fanatics, oil-rich dimwits, and abusers of women" (ebook unpaginated). The one-liners of "postmodern diplomacy" are appropriated from Hollywood action films of the James Bond franchise or violent entertainment that became a staple for Schwarzenegger films in the 1980s and 1990s, such as the action revenge film Commando (1985), the sci-fi-horror blend Predator (1987), or the big-budget action-comedy True Lies (1994). For example, in True Lies, Palestinian Muslim terrorists detonate an atomic bomb in the Florida Keyes. When the Schwarzenegger character, the U.S. special agent Harry, receives the order to kill the terrorists, he quips: "OK, marines. It's time to kick ass." Such incitements to violence, implicitly targeting Muslims, have been used repeatedly in similar movie plot situations (e.g. Navy Seals, 1990; Iron Eagle, 1986; The Delta Force, 1986; Death before Dishonor, 1987). ${ }^{41}$

Compared to the caricatures of citizens of Empire City-the innocent victims of the bombing-the representations of the terrorists show a racial profile with specific patterns of a turban, beards, or bad teeth. The only women depicted are female terrorists wearing a black head scarf. The center of the image shows a silhouette firing at the viewer with the onomatopoeic sound effects of a threefold repetition of the word BLAM. "WE GIVE THEM EXACTLY WHAT THEY WANT / MINUS THE INNOCENT VICTIMS." Visually, Miller seems to answer Jack Shaheen's rhetorical question "what is an Arab" (ebook, unpaginated). For the viewer, the identification of terrorists via 14 caricatures creates a kind of index of racial profiles that are likely to incite racism, prejudice and fear. 

who described the term in the following fashion:

A pattern of stereotypes is not neutral. It is not merely a way of substituting order for the great blooming, buzzing confusion of reality. It is not merely a short cut. It is all these things and something more. It is the guarantee of our self-respect; it is the projection upon the world of our own sense of our own value, our own position and our own rights. The stereotypes are, therefore, highly charged with the feelings that are attached to them. They are the fortress of our tradition, and behind its defences we can continue to feel ourselves safe in the position we occupy. (qtd. in Dyer 11)

However, as Richard Dyer argues, "power relations between a dominant and marginal social group need to be taken into consideration. While stereotypes are essential defined... by their social function" (13), Dyer argues that fictional characters are constructed as archetypes, with typical, recognizable and defining traits. The role of stereotypes is "to make the visible invisible, so that there is no danger of it creeping upon us unawares; and to make fast, firm and separate which is in reality fluid and much closer to the norm than the dominant value system cares to admit" (16).

Miller uses stereotypes of the Muslim "other" as a kind of "short cut" (Dyer 11) in order to take away complexity from the historical, political and cultural encounters surrounding $9 / 11$ and its traumatic aftermath. The negative stereotyping allows Miller to strengthen the values and beliefs of the implied white, Christian, democratically inclined, American readership.

The fourteen caricatures to identify stereotypical Muslim terrorists interact visually with an earlier index of people that represent the victims of the terror attack in the stylized city of New York. Following an abstract site of destruction with the Fixer and Natalie crouching on a platform among the ruins, the speech blurb says: "THE BASTARDS." "HOW MANY OF MY NEIGHBORS HAVE THEY MURDERED?" (unpaginated). What follows on the next three pages are 20,30,30,48, 48 and 160 panels that are supposed to be filled by portraits of neighbors. While the first two sets of panels offer a wide array of white people of various gender and age groups, with each portrait fading more and more into lighter gray colors, the remaining panels are left empty to activate the imagination of the readers based on the first 50 visual references.

The fading panels of Miller's graphic novel interplay with the archives of American visual culture of 9/11. In newspapers and news media, charts of portraits of missing or dead victims circulated. The appropriation and transformation of powerful cultural photographs in the medium of graphic novels show how Miller resignifies conventions, repertoires and visual traditions for the purpose of spreading a sense of Islamophobia. Miller activates what scholars of iconography have called "Bildgedächtnis" (Poeschel 7, Hebel 416). The photographic portraits of victims of the World Trade Center attacks from the website http://americanbuilt.us are a case in point. On first view, the sheer number and small size of images does not allow to differentiate and identify the individuality of the portraits. The viewer needs to zoom into the collage if he/she wants to recognize individual faces. A similar case can be made for those readers who visited the gallery at the National September 11 Memorial Museum, on the trade center site in Lower Manhattan. Here we find nearly 3000 faces of $9 / 11$ victims. The collection has been called a "tapestry of Grief, Loss, Life and Joy" (David W. Dunlap and Susan C. Beachy). The goal of the museum is to achieve an overwhelming effect on the viewer. 
The gallery's walls are filled from floor to ceiling with 3000 5-by-7-inch portraits, arrayed in 250 columns and 12 rows. Only when the viewer moves closer to the walls, he/she can identify individual personalities. Miller reverses this process by starting from simplified black-and-white portraits to ever smaller images until they become empty signifiers. At that state, the viewer is invited to draw on his/her visual media memory to fill in the blanks. Thereby, the identification of the reader with the victims via an emphatic process of filling in the gaps complicates the interpictorial reading. Miller's technique prepares the reader for an emphatic identification with the brutal revenge of the main characters.

While the portraits of the victims suggest diversity, the index of terrorists draw on the stereotype of the bearded Arab who deserve to be killed. The other prominent stereotype not part of the 14 panels, the terrorist with a turban, is featured on the opposite page. The opposition of panels depicting Muslims as terrorists and ethnically diverse Americans provides the basis for an illusory sentiment of multicultural unity in the U.S. with Muslims as the racialized "Other" that should be excluded due to their stigma of terrorism. Islamophobic hatred directed at the Muslim "Other" is paradoxically recruited to reinforce paradigms of American multiculturalism.

When the speech bubble says "WE GIVE THEM EXACTLY WHAT THEY WANT" the reader becomes complicit in the marketing campaign of Legendary Comics mentioned at the beginning of this article: to actively join the Fixer to battle terror on the streets of Empire City aka New York City ${ }^{42}$ The reference to the group of rightful vigilante terrorist fighters-we-functions therefore as a recruitment call to stop the kind of "holy terror" made explicit in the graphic novel. In 2011, when Holy Terror was published, the New York Initiative-and hundreds of people around the world-called itself "real life superheroes" to engage in real-life action. Dressed in superhero costumes such as Batman, a group of crime fighters in New York and other American cities patrolled the streets of the city "to make life better for everyone." ${ }_{43}$

\section{Visualizations of Torture}

In the final part of Holy Terror, Natalie gets caught by the terrorists while she tries to infiltrate the cell dressed like a stereotypical Muslim woman in a black burqa. When captured, she is tied up and appears like a figure about to engage in sadomasochistic practices, as the Muslim terrorists are about to inflict physical pain on her for the sake of pleasure. "THEY USE A LOT MORE ROPE THAN THEY NEED TO," as Natalie observes. She is tied up in a way to emphasize her protruding breasts while she kneels on the ground. A turbaned terrorist leaves no doubt that the sexual undertones are intended. “AND NO, I DIDN'T KEEP YOU ALIVE JUST TO GLOAT. YOUR BEHEADING WILL MAKE A BITCH OF A VIDEO. MAYBE WE'LL DO YOU NUDE” (unpaginated). The sexualization of the hostage situation in which an attractive white woman is about to be tortured by a cartoonish Arab terrorist has been remediated from Hollywood blockbuster films. For example, James Cameron's action comedy True Lies shows the terrorist Salim Abu Aziz, leader of the "Crimson Jihad," in a pseudo-romantic posture using a knife to tease the film's female star, played by Jamie Lee Curtis. She wears a tight black dress which emphasizes her breasts. Like the panel in Holy Terror, the movie scene is set up to humiliate the female star in front of the terrorist fighters. 

the story. One of the most controversial sequence of images in Holy Terror relates to a scene of torture in which the Fixer and Natalie act as revengeful perpetrators. A terrorist with a belt of explosives is strung up on arms and legs with ropes, his face distorted with pain. His body is horizontally dangling in the air while the Fixer is standing on his back. The pressure is particularly strong since Natalie playfully sits on the Fixer's shoulder. Natalie is holding the remote control for the detonator searching for the correct frequency. Since the terrorist does not talk, the Fixer breaks his spine. "YOU'LL NEVER WALK AGAIN." "YOUR EYES ARE NEXT" (unpaginated). Unable to endure the torture any longer, the terrorist reveals the frequency of the detonator. The body is thrown off the roof of a building while Natalie aims the device and presses the red button. Drawn in silhouette, the Fixer and Natalie chat cynically above the letters BOOM: "YEESH. THAT'S A LOT OF CHUNKS OF TERRORIST," to which the Fixer responds "AT LEAST WE KNOW THEY'RE THE SAME SPECIES" suggesting that it is hard to believe that terrorists can be part of the human race (unpaginated).

In a way, Miller's Holy Terror can be considered an aestheticized response to the photographic language of terrorism emerging after $9 / 11$ in the news media. The point of terrorist violence is, as media critic W.J.T. Mitchell points out, "not the killing of the enemy as such, but the terrorizing of the enemy with a traumatizing spectacle" (64). The war of images and words produces an American vigilante who engages in the battle with tactics that evoke the kind of "fire and fury" President Donald Trump threatened to unleash on states who would potentially endanger the United States. ${ }^{44}$ calls the Abu Ghraib Archive (112) - a body of texts and images, recordings and remembrances that is centrally constituted by, but not limited to, the "279 photographs and nineteen video clips gathered by the Army's Criminal Investigation Command (CID)" (112). Two images stand out and have been remediated in many ways, becoming part of our collective memory: the pyramid of seven naked Iraqi men and the Hooded Man on the Box with electric wires tied to his hands. The combination of sex and violence is clearly visible in the visual style of Holy Terror. The stress position of the Hooded Man is part of the Fixer's torture repertoire. The images reflect a kind of pathos formulae that is part of Western painting: a mixture of "obscenity and uncanny holiness" in which imperial powers are glorified and torture is aesthetically justified (Mitchell Cloning, 116). The images of violence and torture from Abu Ghraib are not so much exceptional but rather, as the film maker Errol Morris argues in his documentary film on the genealogy of the Abu Ghraib photographs, represent "standard operating procedures." As such, the violence in Miller's graphic novels, his visual style, the onomatopoetic framing and "regeneration through violence" (Richard Slotkin) ${ }^{45}$ become linked with a sense of empire and self-righteousness complicit with a specific political agenda.

While Miller worked on his graphic novel, public and social media engaged with and disseminated the Abu Ghraib photographs, critical scholarly analyses by Susan Sontag and Mark Danner, Stephen Eisenman, Barbara Ehrenreich and David Levie informed public discourse, and two successful documentary films brought the archive to the attention of a large public: Rory Kennedy's The Ghosts of Abu Ghraib and Errol Morris Standard Operating Procedure (both 2007). The image of "the hooded man," in particular in Morris, gained an iconic status. As cultural critic Rob Kroes reminds us, "[f]rom the 
moment that photographs acquire iconic status and enter the realm of the mass circulation of images, they begin to affect history rather than merely reflecting it" (30). The photograph in question shows an Arab prisoner standing on a box with electric wires attached to his hands and genitals. Should he move or fall off the box, he was told he would be electrocuted. The strategy is to lay the human body in a position of self-torture since any movement to ease the stress is supposed to cause an increase in pain. The image is resonant of Christian iconography with the crucifixion as its iconic tableau (114). By many in the Arab world, the invasion of Iraq was seen as a continuation of the Christian Crusades and a thoroughly imperialistic act. The image of the hooded man seemed like a cynical comment on the link to this part of history.

Despite the public outcry regarding the use of torture and inhumane treatment of Abu Ghraib prisoners, Miller seems to endorse torture as a means to respond to terrorist attacks suggesting that this practice is part of the so-called "postmodern diplomacy" his heroes are engaging with. Director Kathryn Bigelow's Hollywood film Zero Dark Thirty (2012) extends the use of torture in a filmic re-enactment suggesting that with the help of torture Osama bin Laden was tracked down by U.S. military forces. In addition, Miller's remediation of silhouette aesthetics which emerged in the 1920s visual culture of the Harlem Renaissance and has been appropriated by modern media campaigns such as Apple's advertisements for the iPod (see Mehring, "Visual Rhetoric" 182) can be associated with what Thomas Cripps identified as an aesthetic du cool: "outward detachment, composed choreographic strides, and a self-possessed enigmatic mask over inner urgency" (9). Miller merges an American comic code of communication related to (super)heroes fighting criminals with a political agenda to justify violent responses against terrorism and make it look cool.

\section{The Long Shadow of Holy Terror}

While Miller's use of silhouettes helped to turn him into a widely respected and celebrated visual artist, his work on combining silhouetted narratives with the "war on terror" marked a turning point in the reception among many of his fans. Reviews of the book were consistently negative. A blogger on Unleash the Fanby website complains about the change of attitude in Miller's work: "The once astute social observer has been replaced by a racist, sexist, homophobic, xenophobic, paranoid nutcase" (see Paul Young). The reception of the book has been overshadowed by Miller's blog and an entry on the Occupy movement which he posted before the book appeared. ${ }^{46}$ It is worth quoting it at length since it induced a critical reaction to the book suggesting that many commenters did not care to read the novel but turned to the blog and a few images to disavow the product. For example, Miller described the Occupy movement as consisting of a "pack of louts, thieves, and rapists, an unruly mob, fed by Woodstockera nostalgia and putrid false righteousness," claiming that the movement is no "popular uprising. This is garbage... Wake up, pond scum. America is at war against a ruthless enemy." ${ }^{47} \mathrm{He}$ further criticized the attitude of the protesters charging them with ignorance, narcissism and lack of patriotic dedication:

Maybe, between bouts of self-pity and all the other tasty tidbits of narcissism you've been served up in your sheltered, comfy little worlds, you've heard terms like al-Qaeda and Islamicism.

And this enemy of mine-not of yours, apparently-must be getting a dark chuckle, if not an outright horselaugh-out of your vain, childish, self-destructive spectacle. 
In the name of decency, go home to your parents, you losers. Go back to your mommas' basements and play with your Lords of Warcraft.

Or better yet, enlist for the real thing. Maybe our military could whip some of you into shape.

They might not let you babies keep your iPhones, though. Try to soldier on. ${ }^{48}$ heroic representatives of the democratic land of freedom against the stereotypical brutal, barbaric, inhuman Muslim "others" in a fictional graphic novel resonates with what a key Bush aide explained as the agenda of framing historical events. He argued that the "judicious study of discernible reality" should no longer be the basis of the U.S. after 9/11. Rather, he claimed:

That's not the way the world really works anymore. We're an empire now, and when we act, we create our own reality. And while you're studying that realityjudiciously, as you will-we'll act again, creating other new realities, while you can study too, and that's how things will sort out. We're history's actors... and you, all of you, will be left to just study what we do. (Mitchell xviii)

The advertisement for the then new book addressed comic fans expressively by asking them to "join" the main character on his rampage against stereotypical Muslims in the "war on terror." The sad irony of the marketing campaign suggests that Miller is fighting the terror attacks of 9/11 2001 with a new call for counter-terrorism in 2011, now in the disguise of the kind of heroes he has helped to revitalize such as the figure of the Dark Knight, Batman. With its provocative nature in the medium of the graphic novel, Holy Terror does not recognize transcultural processes, for example in the field of literature, music or comedy, where "notions of Muslimness are negotiated in ways that can broaden reader's understanding of the contributions of Muslims to US culture" (Marr 267). As a matter of fact, Holy Terror and its vigilante hero offer an intermedial narrative that erases transcultural processes related to Muslim Americans.

\section{Conclusion}

The power of images and the rhetoric of violence are means to offer closure in intercultural confrontations where the "West"-or western ideals of freedom and democracy-ultimately prevails. The concept of regeneration through violence permeates visual narratives, in particular the world of Frank Miller's graphic novels. Aesthetically, Miller's Holy Terror builds on a transatlantic and transnational media history of appropriating silhouette aesthetics of self-empowerment. His work is in line with Lavater's silhouetted racial profiles, which became part of a racist visual rhetoric in western cultures. ${ }^{49}$ In the realm of comic book narratives, Miller uses mask-like silhouettes in order to frame the heroic struggles of a select few or a single hero against an overbearing system of injustice or a force of evil. Holy Terror does not encourage readers to engage with Islam as a religion but rather foregrounds a cartoonish association of Muslim stereotypes as a threat to the American Way of Life. Silhouetted narratives of Islamophobia became embedded in Miller's creative output including his Batman series The Dark Knight III: The Master Race (2012-15) or the heroic fight of Spartans in 300 or Xerxes. My intermedial reading reveals that the shift from fantasy stories published by Marvel, DC or Dark Horse without an explicit reference to recent historical or political events to a clear-cut propagandistic framing of Holy Terror in order to inspire hatred against the Muslim "Other" created a polarized response. Miller 
is not concerned with what Alsultany has described as a trend in popular television series: "the standardization of 'positive,' sympathetic representations of Arab and Muslim identities" (16). While she sees "antiracism and multiculturalism on the surface" producing "the logics and affects necessary to legitimate racist policies and practices" and projecting "the United States as an enlightened country that has entered a postracial era" (16), Miller sets a strong signal against post-racial fantasies which foreshadows the racist rhetoric of the Trump administration.

Race, as media theoretician W.J.T. Mitchell argues, is not so much a myth and illusion, which we have successfully identified as artificial constructions, but rather it continues to stay with us and informs the way we perceive our environment. If race is not only a reality (visible in texts and images) but also a medium, the iconographic silhouetted narrative of Holy Terror represents a visual language of Islamophobia that functions as a lens rather than a visual object..$^{50}$

Holy Terror exemplifies how the production of images and the framing of war have undergone a radical transformation in entertainment culture. The circulation of the socalled "hooded man" of Abu Ghraib, often represented in silhouette shape in aestheticized versions of the original photograph, has become an iconic image that "undermined the last remaining alibi for the war on terror in Iraq, namely, that it was a moral crusade to liberate Iraq from tyranny" (Mitchell 4). Miller, in turn, uses images of torture, vigilantism, and lustful revenge to counterbalance the use of the hooded man as a kind of recruiting poster for jihadists throughout the Arab world. In Holy Terror, he creates an intermedial discourse with current political images bringing an "emotional truth" to the fight against terrorism. The use of extreme violence, exaggerated forms of stereotyping through silhouette aesthetics, the celebration of vigilantism, sexism and an endorsement of right-wing approaches to a law-and-order mentality place Holy Terror in a continuity of Miller's creative output from Ronin, Batman, Sin City and 300 rather than positioning the work as a remarkable racist exception.

The patriotic agenda behind Holy Terror, however, has changed the perspective on the visual and textual framing in Miller's previous work. Miller's oeuvre must be seen in a new light of radical right-wing agendas to endorse nationalism, a racist agenda regarding immigration policies, extreme forms of violence, and states of exception including the use of torture. Silhouettes are successfully employed and exploited in order to reduce complex socio-political, historical and cultural contexts. Post 9/11 Islamophobia in the graphic novel Holy Terror, with its use of silhouettes to reference a tradition of patriotic superheroes and its built-in counter-narrative of stereotyping media images of terrorism, begs us to modify Richard Dyer's statement that "the effectiveness of stereotypes resides in the way they invoke a consensus" (14) to make room for stereotypes that thrive on in-text dissensus. In the age of fake news, the visual program of "postmodern diplomacy" of Holy Terror turned out to become a visionary tale about a country being pushed towards a politics of "fire and fury." The use of graphic novels as a call to arms to fight terrorism vigilante-style puts limits on Royal's assessment that this visual medium has a remarkable democratic fabric woven into its texture. 


\section{BIBLIOGRAPHY}

24. Created by Joel Surnow and Robert Cochran. Cast: Kiefer Sutherland, Leslie Hope, Mary Lynn Rajskub, Carlos Bernard. Released on Fox Television, 2001-2010.

Abdel-Samad, Abdel. Der Korean. Botschaft der Liebe Botschaft des Hasses. Droemer, 2016.

Acland, Charles R. Residual Media. U of Minnesota P, 2007.

Alberro, Alexander. "Kara Walker," Index vol. 1, no. 1, February 1996.

Allen, Chris. "Islamophobia." The Routledge Handbook on Christian-Muslim Relations, edited by David Thomas, Routledge, 2017, pp. 376-383.

Alsultany, Evelyn. Arabs and Muslims in the Media: Race and Representation after 9/11. New York UP, 2012.

Baetens, Jan. "Graphic Novels." The Cambridge History of the American Novel, edited by Leonard Cassuto, Cambridge UP, 2001, pp. 1137-1153.

Baker, Peter and Choe Sang-Hun, "Trump Threatens 'Fire and Fury' Against North Korea if It Endangers U.S." New York Times, 8 August 2017, accessed 15 April 2020. https:// www.nytimes.com/2017/08/08/world/asia/north-korea-un-sanctions-nuclear-missile-unitednations.html.

Beydoun, Khaled A. American Islamophobia: Understanding the Roots and Rise of Fear. U of California P, 2018.

Bolter, Jay David and Richard Grusin. Remediation: Understanding New Media. MIT Press, 1999.

Brandt, Stefan L. "Intermedial Exchange and the Rhetorics of Islamophobia." Special guest-edited issue of European Journal of American Studies, edited by Elena Furlanetto and Frank Mehring, vol. 3, 2020. https://journals.openedition.org/ejas/

Bremmer, Jan. Us vs. Them: The Failure of Globalism. Penguin, 2018.

Brownstein, Charles. Eisner/Miller. Dark Horse Books, 2005.

Bush, George W. "Address to the United Nations General Assembly by President George W. Bush." 14 September 2005, accessed 12 April 2020. https://2009-2017.state.gov/p/io/potusunga/ 207566.htm.

Colin, Paul, Karen C. C. Dalton, and Henry Louis Gates Jr., Josephine Baker and La Revue Nègre: Paul Colin's Lithographs of "Le Tumulte Noir" in Paris, 1927. Harry N. Abrams, 1998.

Commando. Directed by Mark L. Lester, performances by Arnold Schwarzenegger, Rae Dawn Chong, Alyssa Milano, Vernon Wells, 20th Century Fox, 1985.

Cripps, Thomas. Black Film as Genre. Indiana UP, 1978.

Death before Dishonor. Directed by Terry Leonard, performances by Fred Dryer, Brian Keith, Joanna Pacuła, Paul Winfield, New World Pictures, 1987.

Decker, Christof and Astrid Böger, editors. Transnational Mediations: Negotiating Popular Culture between Europe and the United States. Winter, 2015.

Duncan, Randy, Matthew J. Smith, and Paul Levitz, editors. The Power of Comics: History, Form and Culture. $2^{\text {nd }}$ ed. Bloomsbury Academic, 2015. 
Dunlap, David W. and Susan C. Beachy. "Seeking the Final Faces for a 9/11 Tapestry of Grief, Loss, Life and Joy." The New York Times, 10 September 2016, accessed 15 April 2020. https:// www.nytimes.com/2016/09/11/nyregion/9-11-victims-portraits-national-september-11memorial-museum.html.

Dyer, Richard. The Matter of Images: Essays on Representation. Essays on Representations. $2^{\text {nd }}$ edition. Routledge, 2002.

Epstein, Daniel Robert. "Frank Miller, 300 Interview." UnderGroundOnline, accessed 15 May 2018. http://www.ugo.com/ugo/html/article/?id=16424\&sectionId=106.

Fertig, Mark. Take That Adolf! The Fighting Comic Books of the Second World War. Fantagraphics Books, 2017.

Fluck, Winfried. Romance with Amerika: Essays on Culture, Literature, and American Studies, edited by Laura Bieger and Johannes Völz. Winter, 2009.

Furlanetto, Elena, and Frank Mehring, editors. "Media Agoras: Islamophobia and Inter/ Multimediality: Introduction." Media Agoras: Islamophobia and Inter/Multimediality. Special guestedited issue of European Journal of American Studies, vol. 3, 2020. https://journals.openedition.org/ ejas/.

Georgi-Findlay, Brigitte. "Inter/Multimedial Constructions of Islam in Post-9/11 TV Series: The West Wing and 24." Media Agoras: Islamophobia and Inter/Multimediality, edited by Elena Furlanetto and Frank Mehring, Special guest-edited issue of European Journal of American Studies, vol. 3, 2020. https://journals.openedition.org/ejas/.

Hebel, Udo. "American Pictures and (Trans)National Iconographies: Mapping Interpictorial Clusters in American Studies." American Studies today New Research Agendas, edited by Winfried Fluck, Erik Redling, Sabine Sielke, and Hubert Zapf. Winter, 2014, pp. 401-432.

Homeland. Created by Howard Gordon and Alex Gansa. Showtime, 2011-2020.

Howard, Dave. “"Real life superheroes' fighting crime in New York.” BBC, 12 May 2011, accessed 15 April 2020. http://www.bbc.co.uk/newsbeat/article/13359936/real-life-superheroes-fightingcrime-in-new-york.

Ghosts of Abu Ghraib. Directed by Rory Kennedy. HBO, 2007.

Iron Eagle. Directed by Sidney J. Furie, performances by Louis Gossett Jr., Jason Gedrick, David Suchet, Larry B. Scott, TriStar Pictures, 1986.

Islamophobia Research \& Documentation Project. Center for Race \& Gender, University of California at Berkeley, accessed 11 March 2020. https://www.crg.berkeley.edu/researchprojects/islamophobia-research-documentation-project/.

Itzkoff, Dave. "Purveyor of a Stylish Brutality. The New York Times, 14 August 2014, accessed 14 April 2020. https://www.nytimes.com/2014/08/17/movies/with-a-new-sin-city-film-frankmiller-extends-his-craft.html.

Jackson, E. Nevill. The History of Silhouettes. The Connoisseur, 1911.

Juhasz Antonia, The Bush Agenda: Invading the World, One Economy at a Time. Harper Collins, 2006.

Kirby, Jack and Joe Simon. Captain America Comics. Marvel, 1 March 1941.

Kroes, Rob. Prison Area, Independence Valley: American Paradoxes in Political Life and Popular Culture. Dartmouth College P, 2015. 
Kuper, Peter. Wordless Books: The Original Graphic Novels, edited by David A. Beronä, Harry N. Abrams, 2008.

Lavater, Johann Caspar. Physiognomische Fragmente zur Beförderung der Menschenkenntnis und Menschenliebe. Winterthur, 1775.

Marr, Tim. "Islam and Transnationalism." The Cambridge Companion to Transnational American Literature, edited by Yogita Goyal, Cambridge UP, 2017, pp. 251-268.

Masereel, Frans. Mon livre d'heures: 167 images dessinées et gravées sur bois. Presses de A. Kundig, 1919.

Mehring, Frank "Hard-Boiled Silhouettes: Transnational Remediation and the Art of Omission in Frank Miller's Sin City." Comics at the Crossroads: Transnational Perspectives on Graphic Narratives, edited by Shane Denson, Christina Meyer, and Daniel Stein, Bloomsbury, 2013, pp. 211-228.

--- "How Silhouettes Became 'Black': The Visual Rhetoric of the Harlem Renaissance." Circulation, edited by François Brunet, Terra Foundation for American Art. U of Chicago P 2017, pp. 174-208.

--- "Remediating Silhouettes: What We Can Learn from Advertising the Harlem Renaissance in the Digital Age." Transnational Mediations: Negotiating Popular Culture between Europe and the United States, edited by Christof Decker and Astrid Böger, Winter, 2015, pp. 33-56.

--- The Democratic Gap: Transcultural Confrontations of German Immigrants and the Promise of American Democracy. Winter, 2014.

Miller, Frank. 300. Publication date: May - September 1998. Dark Horse Books, 1999.

--- Batman: Year One. With David Mazzucchelli. Publication date: February - May 1987. Titan Books, 2001.

--- Daredevil. Marvel, 2016.

--- Hard Boiled. Publication date: September 1990 - March 1992. Dark Horse Comics, 1990-1992.

--- Holy Terror. Legendary, 2001.

--- Ronin. DC Comics, 1995.

--- Sin City Library. Publication date: April 1991 - 2000. Dark Horse Books, 2005.

--- The Dark Knight III: The Master Race. With Brian Azzarello. Publication date: November 2015 June 2017. DC Comics, 2017.

--- The Dark Knight Returns. With Klaus Janson and Lynn Varley. Publication date: February - June 1986. Titan Books, 1997.

--- Xerxes. The Fall of the House of Darius and the Rise of Alexander. Dark Horse Books, 2019.

Mitchell, W.J.T. Cloning Terror: The War of Images, 9/11 to the Present. Chicago UP, 2011.

--- What Do Pictures Want? The Lives and Loves of Images. The Chicago UP, 2005.

Morrison, Toni. “On the Backs of Blacks,” Time Magazine, 2 December 1993, accessed 15 April 2020. http://content.time.com/time/magazine/article/0,9171,979736,00.html.

Müller, Friedrich C. Ausführliche Abhandlung über die Silhouetten und deren Zeichnung, Verjüngung, Verzierung und Vervielfältigung. Perrenon, 1780.

Navy Seals. Directed by Lewis Teague, performances by Charlie Sheen, Michael Biehn, Joanne Whalley-Kilmer, Rick Rossovich, Orion Pictures, 1990.

Otomo, Katsuhiro. Akira. Kodansha Comics, 2009. 
Oxford English Dictionary, online version, accessed 15 April 2020. https://www-oed-com

Paech, J., and Schröter, J., eds. Intermedialität-Analog /Digital: Theorien, Methoden, Analysen. Wilhelm Fink Verlag, 2007.

Pannor, Stefan. "Neuer Comic von Frank MillerDer dumpfe Ritter kehrt zurück." Der Spiegel, 4 November 2011, accessed 20 April 2020. https://www.spiegel.de/kultur/literatur/neuer-comicvon-frank-miller-der-dumpfe-ritter-kehrt-zurueck-a-794590.html.

Poeschel, Sabine, editor. Ikonographie. WBG, 2010.

Predator. Directed by John McTierman, performances by Arnold Schwarzenegger, Carl Weathers, Bill Duke, Jesse Ventura, 20th Century Fox, 1987.

Rajewsky, Irina O. "Intermediality, Intertextuality, and Remediation: A Literary Perspective on Intermediality.” Intermédialités, vol. 6, Fall 2005, pp. 43-64.

Reel Bad Arabs: How Hollywood Vilifies a People. Directed by Sut Jhally. 2006.

Rippl, Gabriele. "Introduction." Handbook of Intermediality: Literature-Image-Sound-Music, edited by Gabriele Rippl, De Gruyter, 2015, pp. 1-31.

Royal, Derek Parker. “Foreword.” Multicultural Comics: From Zap to Blue Beetle, edited by Frederick Luis Aldama, U of Texas P, 2010, pp. ix-xi.

Schindler's List. Directed by Steven Spielberg, performances by Liam Neeson, Ben Kingsley, Ralph Fiennes, Caroline Goodall, Universal Pictures, 1993.

Shaheen, Jack G. Reel Bad Arabs: How Hollywood Vilifies a People (Revised and updated ed.). Olive Branch Press, Interlink Publishing Group, 2012.

Slotkin, Richard. Regeneration through Violence: The Mythology of the American Frontier, 1600-1860. U of Oklahoma P, 1973.

Snyder, Zack. 300: The Ultimate Experience. BluRay Booklet. Warner Brothers, 2009.

Standard Operating Procedure. Directed by Erroll Morris, Sony Pictures Classics, 2007.

Stein, Daniel. "Comics and Graphic Novels." Handbook of Intermediality: Literature-Image-SoundMusic, edited by Gabriele Rippl, De Gruyter, 2015, pp. 420-438.

Taylor, Alan. "9/11: The Day of the Attacks." The Atlantic, 8 September 2011, accessed 15 April 2020. https://www.theatlantic.com/photo/2011/09/911-the-day-of-the-attacks/100143/.

The 300 Spartans. Directed by Rudolph Maté, performances by Richard Egan, Sir Ralph Richardson, Diane Baker, Barry Coe, 20th Century Fox, 1962.

The Delta Force. Directed by Menahem Golan, performances by Chuck Norris, Lee Marvin, Martin Balsam, Joey Bishop, The Cannon Group, 1986.

True Lies. Directed by James Cameron, performances by Arnold Schwarzenegger, Jamie Lee Curtis, Tom Arnold, Art Malik, Bill Paxton, $20^{\text {th }}$ Century Fox, 1994.

Waid, Mark. "Preface." The Power of Comics. History, Form and Culture, edited by Randy Duncan, Matthew J. Smith, and Paul Levitz, $2^{\text {nd }}$ ed, Bloomsbury Academic, 2015, pp. viii-x.

Walker, Kara. Endless Conundrum. An African Anonymous Adventuress. Walker Art Center, accessed 15 April 2020. https://walkerart.org/collections/artworks/endless-conundrum-an-africananonymous-adventuress. 
--- Kara Walker, My Complement, My Enemy, My Oppressor, My Love, organized by Philippe Vergne, Sander Gilman, Kevin Young, Thomas McEviley, Robert Storr, and Gwendolyn DuBois Shaw. Hatje Cantz, 2007.

Ward, Lynd. Madman's Drum: A Novel in Woodcuts. Jonathan Cape and Harrison Smith, 1930.

--- Wild Pilgrimage. H. Smith \& R. Haas, 1932.

West Wing, The. Created by Aaron Sorkin. NBC, 1999-2006.

Williams, Raymond. Culture and Society, 1780-1950. Columbia UP, 1983.

Wolff, Michael. Fire and Fury: Inside the Trump White House. Henry Holt and Company, 2018.

Young, Paul. Frank Miller's Daredevil and the Ends of Heroism. Rutgers UP, 2016.

Young, Philip. American Fiction, American Myth: Essays. Pennsylvania State UP, 2000.

Zachar, Peter. "Fact and Value in Emotion: An Introduction and Historical Review." Fact and Value in Emotion, edited by Louis C. Charland and Peter Zachar, John Benjamins Publishing Company, 2008, pp. 1-14.

Zero Dark Thirty. Directed by Kathlyn Bigelow, performances by Jessica Chastain, Jason Clarke, Joel Edgerton, Jennifer Ehle, Sony Pictures Releasing, 2012.

\section{NOTES}

1. See https://www.superrobotmayhem.com/comics/the-fixer/holy-terror/.

2. See Frank Mehring "Hard-Boiled Silhouettes: Transnational Remediation and the Art of Omission in Frank Miller's Sin City."

3. Miller originally intended to write a Batman installment about him fighting against terrorists but decided to introduce a new character while working on the topic. See Stefan Pannor, "Neuer Comic von Frank Miller: Der dumpfe Ritter kehrt zurück."

4. For discussion of this iconic cover see Mark Fertig's book Take That Adolf! The Fighting Comic Books of the Second World War.

5. In an interview from 2005 with Will Eisner, Miller pointed out that he considered it problematic that a certain blockbuster mentality from the world of film translated more and more into the world of comics. "I think comic books are too obsessed with the same blockbuster mentality that makes bad movies" (149). The blockbuster marketing campaign was enhanced by a 1:46 min trailer to announce the upcoming book in sensational fashion with booming sound effects and animated panels from the graphic novel. See https://www.legendary.com/comics/frank-millers-holy-terror/.

6. See https://www.superrobotmayhem.com/comics/the-fixer/holy-terror/.

7. Intermediality as a theoretical concept has been most widely used with reference to "multiple discourses and modalities of experience and representation, as examined in aesthetic and other humanistic traditions of communication research" (Paech and Schröter, 10, see also Jensen). I agree with W. J. T. Mitchell that "all media are mixed media" (211). This is particularly obvious for the medium of graphic novels with its peculiar blend of text and visuals. I am building on the work of American Studies scholars such as Astrid Böger, Christof Decker, Winfried Fluck, Udo Hebel, Gabriele Rippl, and Daniel Stein (among many others) to investigate the complex dialogues of 
textual studies with visual studies with a specific focus on the interpictorial and intermedial discourse of the silhouette aesthetics in Miller's propagandistic work on terrorism in Holy Terror.

8. See Philip Young, American Fiction, American Myth: Essays, 127.

9. As a matter of fact, Miller wrote a three-issue comic book mini-series called Hard Boiled (drawn by Geof Darrow) about a dystopian future Los Angeles, published between 1990 and 1992 by Dark Horse Comics.

10. For a general overview of theoretical and conceptual aspects of comics and graphic novels, see Daniel Stein's article "Comics and Graphic Novels." In my analysis of Holy Terror I understand graphic novels not only as a "combination of images and words as they unfold in sequences of panels... determined by the materiality of the page as well as different publication formats" (420) but also add references to interpictorial sources (or "clusters" in the sense of Hebel) as a key element intermediality.

11. See the introduction to our EJAS special guest-edited edition on "Media Agoras."

12. See also Stefan L. Brandt, "Intermedial Exchange and the Rhetorics of Islamophobia."

13. My understanding of remediation indicated a process that Bolter and Grusin describe as media "continually commenting upon, reproducing and replacing each other" (22). Turning to Jacques Derrida's argument that there is nothing prior to writing, they claim that correspondingly that for visual culture "there is nothing prior to mediation. Any act of mediation is dependent upon another, indeed many other, acts of mediation and is therefore remediation" (Bolter and Grusin 18). If we agree with Marshall McLuhan that new media often make us more self-conscious of their predecessors, we should as in which ways Miller draws on "residual media" (Charles R. Acland $\mathrm{xx}$ ) by reconfiguring, renewing, and recycling visual styles that have been neglected, abandoned, or thrashed over the course of time.

14. The issue of Islamophobia became visible in Miller's graphic novel 300 (1998) about the historical battle between Sparta and Persia. However, this work did not produce a controversial discussion on cultural Othering and racism at the time.

15. While 300 received generally positive reviews, Holy Terror and Xerxes were criticized for their racist, anti-Muslim stereotyping and muddled plot structure. See e.g. www.goodreads.com. The visual approach to framing the action remains surprisingly consistent.

16. He also reminds us of an earlier model of "the image as a living thing" due to its metaphorical qualities (Cloning Terror, xix).

17. See in this context my essay "How Silhouettes Became 'Black': The Visual Rhetoric of the Harlem Renaissance."

18. Silhouettes offer a remarkably rich, unexplored corpus of images emerging from ancient Greece and China, transmitted via the Western culture of portraiture and twenty-first-century advertising to the digital age of remediation and global image distribution processes. The novel functions of silhouettes in American modernist advertisement and art create unforeseen opportunities of intercultural communication. Because of their close relationship to stereotypes, it is of central importance to also analyze how silhouettes can lead to misunderstandings and intercultural confrontations. In the first case, silhouettes signify a democratic promise of aesthetic empowerment transcending national and cultural boundaries. In the 
second case, silhouettes can trigger projections that rely on colonial fantasies, asymmetric gender power relations, or contribute to a feeling of national exceptionalism via an iconographic mythical textual-visual narratives. This paradoxical effect needs explaining.

19. See Oxford English Dictionary, online version, https://www-oed-com.

20. Sometimes we also encounter portraits that are cut on white paper and mounted on black. While the roots of silhouettes can be traced to Paleolithic times in which vases from ancient Greece show black figures in profile, Pliny the Elder connects silhouettes in his Natural History (AD 77-79) with the very origins of art. Pliny describes how in 600 BC Dibutades, the daughter of a Corinthian potter, traced the profile of her lover on a wall before he left on a journey

21. In Germany, silhouette art reached its climax in the second part of the eighteenth century, with its centers in Weimar, Dessau, and Berlin. In 1779, Friedrich C. Müller provided the first overview in his book Ausführliche Abhandlung über die Silhouetten und deren Zeichnung, Verjüngung, Verzierung und Vervielfältigung. With the silhouette chair and the so-called Storchschnabel, a technical device created by the Jesuit Christoph Schreiner in the early seventeenth century, silhouettes could be created in a mechanical fashion. For a comprehensive analysis of the genealogy of silhouettes in western art, see my essay “How Silhouettes Became 'Black': The Visual Rhetoric of the Harlem Renaissance” (2017).

22. Masereel's influential work Mon livre d'heures: 167 images dessinées et gravées sur bois (1919, later published under the title My Book of Hours in 1922 and afterward as Passionate Journey in 1948) traces the arrival of a young man in a prototypical European metropolis after World War I. The black-and-white images tell of moments of crisis and tragedy and the isolation of urban life. Weary of civilization, the protagonist embarks on a quest for redemption and inspiration in "primitivist cultures." After his return to the city, the young man assumes a carefree attitude of complete freedom and independence. Masereel's visual style is intrinsically linked to the fine arts. It would soon be appropriated by the commercial arts in the field of advertisement.

23. In the latter, Ward uses the Expressionist techniques of woodcut prints to confront his protagonist with the practice of lynching, contrasting the more detailed figures of the aggressors in white with the black silhouetted body of an African American with a rope around his neck hanging from a tree. Woodcut novels are thus one of the "missing links" in the circulation of images that triggered a renewed interest in the art of silhouettes to advertise the African American naissance in literature, art, and music in the United States.

24. For an example of the period's many distorting representations of African Americans as "savage" and "carnal," see e.g. Paul Colin's lithographs of the caged, halfnaked Josephine Baker (1927) for the revue Le Tumulte Noir in Paris. For a discussion of the relationship between Winold Reiss and Aaron Douglas, see Frank Mehring, The Democratic Gap: Transcultural Confrontations of German Immigrants and the Promise of American Democracy.

25. See e.g. my essay "Remediating Silhouettes: What We Can Learn from Advertising the Harlem Renaissance in the Digital Age."

26. Miller shares a tradition of silhouettes as artistic provocation with Karen Walker. Walker's silhouettes most often reference African American people. She builds on a 
cultural memory in which representations of blackness are tied to stereotypical silhouettes. This is remarkable considering that during the heyday of their popularity in the eighteenth and early nineteenth centuries, silhouettes represented the likeness of mostly white bourgeois sitters. For example, Endless Conundrum, An African Anonymous Adventuress (2001) shows a tableau of various silhouettes, which in some form or another critically engage with issues of slavery, sexual exploitation, violence against African Americans, and deconstructing modernist aesthetics. "My works are erotically explicit, shameless. I would be happy if visitors would stand in front of my work and even feel a little ashamed because they have... simply believed in the project of modernism," explains Walker (62). Hence, Walker's silhouettes are both beautifully attractive and shockingly repulsive.

27. Kara Walker, quoted in Alexander Alberro, "Kara Walker," 25. See also Kara Walker, My Complement, My Enemy, My Oppressor, My Love.

28. The appropriation of silhouette aesthetics in the murals of Walker has inspired new scholarship on negative or thoughtlessly stereotyped representations of blacks in the context of American minstrelsy. See the work of scholars such as Philippe Vergne, Sander Gilman, Kevin Young, Thomas McEviley, Robert Storr, and Gwendolyn DuBois Shaw.

29. Toni Morrison, "On the Backs of Blacks."

30. This transfer is even more complicated considering that prominent African Americans such Muhammed Ali and Malcolm X, among many other, identified themselves as Muslims. See in this contexts Khaled A. Beydoun's American Islamophobia: Understanding the Roots and Rise of Fear, $152 \mathrm{ff}$.

31. George W. Bush called for a "coalition of the willing" (consisting of nations that are either "with" or "against us") to expand "international trade policies in the name of fighting terrorism and spreading freedom" (Juhasz 4). The so-called Bush agenda expressed in his Address to the United Nations General Assembly on 14 Sep. 2005 "for freer trade" as part of a "free world" called for a simplified albeit compelling vision of division US vs. Them (Bremmer 2).

32. This approach is notably different from Miller's revisionist work on The Dark Knight Returns where Gotham City's authorities have often been highly critical of Batman's vigilante killing sprees calling him a "menace" to society (unpaginated).

33. The name "Mohammed" is in and of itself kind of silhouette. It de-humanizes and de-personalizes the terrorist (and the Muslim other) by depriving him of cultural and personal specificities, similar to what the silhouette does on paper.

34. The discourse on the propoer translation of jihad and the reference to infidels has sparked numerous interpretations and needs to be seen in the specific historical context in which the Quran was written. For a discussion of the different meanings, translations, and interpretations, see e.g. Hamed Abdel-Samad, Der Korean. Botschaft der Liebe Botschaft des Hasses.

35. The fact that a widely mediated event such as the Boston Marathon bombing happened two years after the appearance of Holy Terror makes the reading experience all the more powerful today.

36. In the following, I will refer to the photographs indexed by The Atlantic from 50 iconic images. Alan Taylor "9/11: The Day of the Attacks." The following numbers of illustrations refer to the photographs collected on the website of The Atlantic. 
37. See Mehring "Hard-Boiled Silhouettes" (2013).

38. I follow the 1991 Runnymede Trust Report's definition of Islamophobia as "unfounded hostility towards Muslims, and therefore fear or dislike of all or most Muslims." See the ISLAMOPHOBIA RESEARCH \& DOCUMENTATION PROJECT.

39. For example, 300 traces the Battle of Thermopylae and the events leading up to it from the perspective of Leonidas of Sparta. The series won three Eisner Awards in 1999 including "Best Limited Series," "Best Writer/Artist" for Frank Miller and "Best Colorist" for Lynn Varley. It was turned into a successful Hollywood film by Zack Snyder in 2006. Miller first came into contact with the ancient history of Sparta through the medium of film. As a young boy he saw Rudolf Mathe's epic history drama The 300 Spartans on the Battle of Thermopylae in cinemascope. This left a particular impression on the young man's mind. What struck him most was the representation of heroism which did not lead to a happy ending with decorations but rather death for the cause of freedom and patriotism. 300 represents a remarkable visual accomplishment that departs from the traditional letter size format in favor of a large horizontal framing that reflects the viewing traditions of widescreen films. This format has also been chosen for Holy Terror suggesting an aesthetic and narrative link between the defense of heroic Greek values and what Miller defines as American "core beliefs." Prior to his work on 300, Miller already included a reference to the Hot Gates in his hard-boiled noir graphic novel series Sin City. In The Big Fat Kill, Miller foreshadows his efforts to bring a silhouetted noir aesthetics to the classic battle in which the underdogs show extraordinary strength and courage in a seemingly hopeless situation or war. Afterwards, Miller followed a double strategy: 1) learning as much as possible about the historical events, including a three week-trip to the Aegean to study the Greek environment and visit the Hot Gates to absorb the atmosphere, 2) to transcend historical accurateness in order to convey a universal narrative. Miller explained that he was touched by the terrific, glorious events that happened at the hot gates. He recognized that at the epicenter of the historical battle one could deduct something about the quintessential nature of western civilization (see booklet). Miller was interested in creating a narrative which would connect the courage of the 300 Spartans with a sense of American freedom. In that sense, 300 could be read as a kind of homage to those resistance fighters who, in Miller's mind, form the basis for the vigilante warriors of $21^{\text {st }}$ century narratives in Holy Terror. Rather than approaching the events historically, the graphic novel is interested in a kind of emotional truth (Zack Snyder, 21). While supremacist narratives of pride, glory, power, aggression and violence are the ultima ratio for Miller's aestheticization of the Spartans, it becomes problematic when similar concepts are projected on the "war on terror" in twenty-first-century American democratic frameworks.

40. The sparse use of color, particularly green and red, emphasizes a human dimension within the distorted image of the ruins caused by the detonations.

41. For an overview of Muslim stereotypes in True Lies, see Shaheen's Reel Bad Arabs.

42. See epigram of this article.

43. See Dave Howard, "'Real life superheroes' fighting crime in New York."

44. See in this context Peter Baker and Choe Sang-Hun, "Trump Threatens 'Fire and Fury' Against North Korea if It Endangers U.S." The term became the title of the book 
Fire and Fury: Inside the Trump White House (2018) by journalist Michael Wolff to describe the political rhetoric and work of President Donald Trump.

45. Slotkin argues that the mythological figure of the American hero formed a new national identity in violent, wilderness regeneration in the white-Indian encounter.

46. Despite the explicit agenda of being a piece of propaganda to arouse patriotism, the critical reception of Holy Terror went along with an appreciation for Miller's earlier work.

47. See http://frankmillerink.com/.

48. See http://frankmillerink.com/.

49. See Mehring 2017.

50. I have shown in another context that the use of silhouettes in American advertisement has established a visual language of race that exploits stereotypical assumptions about "blackness." See "Remediating Silhouettes," 36 and 52.

\section{ABSTRACTS}

The graphic artist Frank Miller represents an innovative force in the field of graphic novels who pushes the medium into new territories. One such territory is Islamophobia and terrorism in his graphic novel Holy Terror (2011). This article explores how Islamophobia has been mediated and how media systems of the twenty-first century forge Islamophobia into new shapes asking: How does Frank Miller's aesthetics of silhouetted bodies reframe Islamophobia in an interpictorial and intermedial discourse of images? To what extent do Miller's graphic stylizations of Islamophobia remediate elements of his previous work on fictional (super)heroes and historical leaders from Batman to the 300 Spartans? I argue that Miller's visual narrative participates in the Islamophobic discourse of American popular culture by appropriating a wide array of popular culture visual archives for a propagandistic call for Muslim "Othering." Holy Terror references news media, films and television series, 9/11 photography, familiar comic book heroes, and, of course, Miller's own oeuvre. Thus, the graphic novel represents what I conceive as a virtual agora where different media converge to negotiate public discourses on Islamophobia. I will turn to the medium of graphic novels to first reveal how Miller's narratives and silhouette aesthetics of (super)heroes have become complicit with Islamophobic responses to the crisis of 9/11; second, to trace the discourse of Islamophobia in post-9/11 America in Miller's work; and, third, to reveal how this discourse interlinks with the patriotic logic of the fight against terrorism.

\section{INDEX}

Keywords: Islamophobia, Intermediality, Frank Miller, Graphic Novels, Holy Terror (2011) 


\section{AUTHOR}

\section{FRANK MEHRING}

Frank Mehring is chair and professor of American Studies at Radboud University, Nijmegen. He teaches twentieth- and twenty-first century visual culture, music, and theories of transatlantic studies. In 2012, he received from the European Association for American Studies the biennial Rob Kroes Award for his monograph The Democratic Gap (2014). His publications include Sphere Melodies (2003) on Charles Ives and John Cage, Soundtrack of Liberation (2015) on WWII sonic diplomacy, Sound and Vision: Intermediality and American Music (2018, with Erik Redling) The Mexico Diary: Winold Reiss Between Vogue Mexico and the Harlem Renaissance (2016), The Multicultural Modernism of Winold Reiss (2020), and The Politics and Cultures of Liberation (2018, with Hans Bak and Mathilde Roza). Frank is the co-founder of the European Digital Studies Network and the online journal AmLit - American Literatures (together with Stefan L. Brandt and Tatiani Rapatzikou). Frank is a board member of the International Committee of the American Studies Association, the European American Studies Association and the Netherlands American Studies Association. He organized the first international symposium on Winold Reiss in Berlin and cocurated exhibitions on Winold Reiss, the Marshall Plan, and Liberation Songs in New York, Nijmegen and The Hague. 